\title{
Examining Jamaican Teachers' Global Perspectives: Prospects for Vision 2030 Jamaica
}

\author{
Flavia Iuspa ${ }^{1}$, Sarah Mathews ${ }^{1} \&$ George Dawkins ${ }^{2}$ \\ ${ }^{1}$ College of Education, Florida International University, Miami, USA \\ ${ }^{2}$ Shortwood Teachers' College, Kingston, Jamaica \\ Correspondence: Dr. Flavia Iuspa, College of Education, Florida International University, $11200 \mathrm{SW} 8^{\text {th }}$ Street, Miami, \\ FL, 33199, USA. Tel: 305-348-3392.
}

Received: October 30, 2015

Accepted: November 17, 2015

Online Published: November 20, 2015

doi:10.5430/irhe.v1n1p19

URL: http://dx.doi.org/10.5430/irhe.v1n1p19

\begin{abstract}
Vision 2030 Jamaica calls for an education that prepares global citizens. Teachers play a pivotal role in fulfilling a nation's educational goals. This paper presents a quantitative study exploring Jamaican in-service teachers' global perspectives. The Global Perspective Inventory served as the study's theoretical framework. The study found that teachers reported a neutral disposition to the significance of one's cultural context to determine which knowledge is relevant, a high intrapersonal score, and mix tendencies on the interpersonal-social interaction scale. The results intended to advance teachers' global perspective awareness and identify possible areas of curriculum development.
\end{abstract}

Keywords: in-service teachers' global perspectives, global perspective, global education, assessment, global perspective inventory, Jamaican teacher's global perspectives

The world is becoming increasingly more globally-connected through transnational migration, increased access to the internet, on-line social networking, and the growth of multinational corporations (Palfry \& Gasser, 2008; Suarez-Orozco, 2004; Castles, 2007). A neoliberal view presents globalization as an "uncontrollable herd" (Friedman, 2012) that leads groups and nations towards human prosperity (Marber, 2013). According to this view of globalization, cultural groups around the world are urged to engage globally or risk being left behind. Other views suggest that even though we are "more wired" we have yet to experience a borderless global society where "geography, language and distance" no longer matter (Ghemawat, 2007, p. 3). Scholars suggest that despite globalization, or possibly as a result of globalization, distinctions between the "haves" and "have not" remain (Merryfield \& Subedi, 2006; Merryfield \& Wilson, 2005).

Globalization processes create a need to adjust education goals of each country to ensure that the current and future workforce is globally competent. Global education provides a foundation to become a globally competent citizen. According to Boix-Mansilla and Jackson (2011), global competency is defined as "the capacity and disposition to understand and act on issues of global significance (p. xiii). This definition implies that individuals will need to develop a global perspective (understand and consider other perspectives when acting on issues) in order to become globally competent. Global education provides individuals with the skills, knowledge, and perspectives they need to visualize themselves as a part of a greater human community dedicated to protecting the environment, respecting a set of universal human rights, and willing to act on global issues (Becker, 1979; Gaudelli, 2003; Landorf, 2009; Noddings, 2005; Pike, 2015).

The Ministry of Education of Jamaica emphasizes that it is an important role of Jamaican citizens to become globally competent citizens not only for national development but also to increase Jamaica's global competitiveness (Government of Jamaica, 2012). This reflects directly in Vision 2030 Jamaica - a national development plan that has been designed to bring the country to a developed level by 2030. In order to prepare Jamaican citizens the Vision 2030 document outlined a profile of "the educated Jamaican." This profile included the ability to be "agile of mind, able to adjust to different situations" and "speak an additional language," as well as developing a perspective that is "tolerant of diversity" and "committed to a sustainable lifestyle" (Government of Jamaica, 2012, p. 57). The educational goals, outlined in the Vision 2030, that address environmental sustainability, problem-solving skills, and transforming social inequalities are consistent with the goals of global education. 
Since this is such a complex process, global educators recommend implementing a global perspective and promoting awareness of global interconnectedness throughout all levels of curricula (Abdullahi, 2010; Bruce, Podemski, \& Anderson, 1991; Zhao, 2009). Teachers that successfully incorporate global education into their curricula must have a well-developed global perspective themselves (Merryfield \& Wilson, 2005). As the Jamaican nation prepares for globalization, it is important for Jamaican educators to have a mature global perspective to prepare globally competent students (Bruce, Podemski, \& Anderson, 1991; Zhao, 2010; Zong, 2009). The purpose of this paper is to explore Jamaican in-service teachers' global perspectives to shed light on this facet of global education within Jamaican schools.

\section{Hanvey and the Origins of Global Perspective Development}

As one of the early scholars in global education, Robert G. Hanvey (1976) proposed five major components of global education that are still relevant for developing a global perspective today. Perspective consciousness is the recognition that worldviews are not universal and that one's own view of the world may not be shared by others. 'State of the planet' awareness refers to an individuals' knowledge of world systems, conditions, and trends, with an emphasis on the basic information about the world and world events. Cross-cultural awareness includes the ability to recognize, respect, and identify with different world cultures. In regards, to cross-cultural awareness, Hanvey (1976) suggests that individuals can evolve through a variety of stages of participation: contact, demonstrating respect for others, developing empathy for others, and transspection, or "putting oneself into the heads of others" (p. 18). When a student develops knowledge of global dynamics, they are able to understand the world as a system, identify interrelationships between societies, and realize that there are ramifications, intended and unintended, for every action. Finally, through the awareness of human choices dimension individuals learn about different global choices and responsibilities in order to act as world citizens.

Many global educators divide Hanvey's components into the substantive domain - i.e. the mastery of relative information about the world and the ability to make connections between global systems - and perceptual domain i.e. dispositions or perceptual frameworks that impact the way one looks at the world (Mason \& Serriere, 2008; Merryfield \& Wilson, 2005; Wilson, 1983). While it may be easy for teachers to deliver global content to students, addressing the substantive aspect, it is often difficult to shape individuals' dispositions or perspectives, the perceptual aspect, through formal education. The perceptual realm requires recognition of how individuals "construct events and issues through their own histories, cultural lenses, knowledge bases and experiences" (Merryfield \& Wilson, 2005,p. 18). As many global educators point out, this often requires multiple encounters with diverse views, intense reflection on one's experiences and perspectives, and the courage to challenge one's taken-for-granted assumptions (Doscher \& Landorf, 2013).

\section{Global Perspective Inventory Theoretical Framework}

Just as it is difficult to "teach" the perceptual aspects of global perspectives, it is also difficult to assess an individuals' mastery of such dispositions. Braskamp, Braskamp, and Engberg (2013) have developed a framework to measure one's global perspective based on Robert Kegan's (1994) theories of psychological development. Kegan's theory identified three domains of human development: cognitive, intrapersonal, and interpersonal. The Cognitive Domain, addresses the question "How do I know?" and includes a reflection on what we know or do not know to be true. The Intrapersonal Domain requires the ability to question, "Who am I?" and relies on self-awareness and integration of one's self-identity. The third domain, the Interpersonal Domain indicates an individual's ability to engage with others, as they contemplate the question "How do I relate to others?" (Braskamp et al., 2013, p. 3).

Braskamp et al. (2013) utilized this framework to develop the Global Perspective Inventory (GPI). The GPI evaluates individuals' levels of global perspective based on the above mentioned domains. Each of the three domains is divided into two scales, development and acquisition, and the results measure an individual's level of global perspective in relation to these scales. The two scales in the cognitive domain are Knowing - or the ability to recognize cultural contexts when judging what is important to know-, and Knowledge, - or one's awareness of other cultures. The two scales in the intrapersonal domain are Identity -one's awareness of how ethnicity, race, and gender impact one's identity-, and Affect, - the level of respect for or acceptance of diverse cultural perspectives. The interpersonal domain is composed of Social Responsibility, "the level of interdependence and social concern for others," and Social Interaction, the "degree of engagement with others who are different from oneself and degree of cultural sensitivity" (Braskamp et al., 2013, p. 5).

Three additional sets of items were added in 2009 to reflect the "sociocultural characteristics of campuses based on previously conducted research concerning the structure of successful experiences within institutions of higher 
education" (Braskamp et al. 2013, p. 5; see also Braskamp, Trautvetter, \& Ward, 2006). The three additional clusters included questions that examine the university's curriculum, community, and co-curricular activities.

\section{Methodology}

This quantitative study focused on assessing Jamaican teachers' global perspectives and possible experiences that influence their global perspective development. This research method was chosen primarily based on the nature of the two research questions that provided direction for the study:

1. What is the global perspective profile of the selected in-service Jamaican teachers?

2. Is there a statistically significant difference in teachers' global perspectives GPI sub-scales by demographic characteristics and experiences abroad?

\subsection{Data Collection Instruments}

Participants. The study used a purposive sampling $(\mathrm{N}=280)$ of practicing and in-service teachers that teach at the early childhood, primary, or secondary level in Kingston, Jamaica. These schools were selected due to the third author's connections to the schools. The researchers chose teachers with at least one year of professional experience as criteria to determine which participants to include in this study. A pilot study $(\mathrm{n}=27)$ was completed during the fall 2012 to determine if the GPI questions were clear to the Jamaican target populations. No revisions on the GPI survey were necessary.

\subsubsection{Global Perspective Inventory Survey}

The GPI, which served as the primary data collection instrument, consisted of a total of 76 items distributed in the following manner: 40 were closed ended items based on a five-point Likert scale, from strongly agree (represented as 5) to strongly disagree (represented as 1), except for 10 reversed-scored items. The remaining 36 items in the survey covered questions pertaining the community, curriculum, co-curricular activities, and demographics. The instrument was distributed to the participants during the spring 2013 term.

\subsubsection{GPI Survey Distribution}

Prior to distributing the survey to the teachers from the three schools, the researchers requested permission from the respective schools' principals. Once approval was granted, the third author met with the schools' teachers during their teaching planning periods or lunchtime to explain the purpose of the study. At this point the teachers signed the Consent to Participate form and completed the GPI survey.

\section{Data Analysis}

\section{GPI Survey}

The quantitative data obtained from the surveys' responses were analyzed in the following manner: First, descriptive statistics were computed using the GPI survey results. Descriptive statistics provided a preliminary summary of the respondents' central tendencies for each of the items measured. This analysis addressed research question 1, "What is the global perspective profile of the selected Jamaican teachers?"

In order to answer research question 2, "Is there a statistically significant difference in teachers' global perspective scales and subcategories by: (a) gender; (b) age group, (c) level of teaching preparation, and (d) experience abroad?" Independent T-test and Analysis of Variance (ANOVA) were performed.

\section{Findings}

\subsection{Participants}

The GPI was distributed to a total of 280 teachers in Kingston, Jamaica schools during spring 2014. Of the N=280, $\mathrm{n}=176$ were received leading to a response rate of $63 \%$. The demographics data collected showed that the $89 \%$ percent of the respondents were females, $59 \%$ full-time teachers, and $42 \%$ hold a bachelor's degree in education. Regarding the field of study, 24\% reported Education and Social Work, 18\% Arts and Humanities, 11\% Physical and Biological Sciences and Math, and 36\% other. $91 \%$ of the respondents reported not having participated in study abroad, and $94 \%$ have never lived abroad.

\subsection{Global Perspective Inventory Results}

Question 1 of the study asks, What is the global perspective profile of the selected Jamaican teachers? The following section presents the descriptive statistics for the corresponding GPI subscales in order to address this research question. 


\subsubsection{Cognitive Dimension Descriptive Statistics}

\subsubsection{The Knowing Scale}

The Knowing scale is composed of 8 items showing the "degree of complexity of one's views of the importance of cultural context in judging what is important to know and value" (Braskamp et al., 2013: p. 5). The Knowing scale has an average mean score of 2.8. This mean score seems to indicate a neutral disposition from the respondents to the overall significance of one's cultural context in determining what is relevant to know and value.

This neutral disposition is reported in the following item Cultural differences make me question what is really true $(\mathrm{M}=2.72)$, with $45 \%$ of the respondents strongly agreeing and agreeing, $25 \%$ neutral, and $31 \%$ disagreeing and strongly disagreeing. This is also demonstrated in the reverse items: When I notice cultural differences, my culture tends to have the better approach $(\mathrm{M}=2.49)$, with $52 \%$ of the respondents strongly agreeing and agreeing, and $35 \%$ neutral; In different settings what is right and wrong is simple to determine $(\mathrm{M}=2.52)$ with $59 \%$ of the respondents strongly agreeing and agreeing, and $17 \%$ neutral.

Despite the neutral tendencies, some items' results indicate that respondents do recognize some degree of importance of culture in shaping one's perspectives: I take into account different perspectives before drawing conclusions about the world around me $(\mathrm{M}=1.99)$, with $82 \%$ of the respondents agreeing and strongly agreeing with the statement, $I$ consider different cultural perspectives when evaluating global problems $(\mathrm{M}=2.33)$ with $62 \%$ of the respondents agreeing and strongly agreeing with the statement. Finally, two items relevant to mention are: I rely primarily on authorities to determine what is true in the world $(\mathrm{M}=3.68)$ and I rarely question what I have been taught about the world around me $(\mathrm{M}=3.40)$. Both items show that $64 \%$ and $51 \%$ of the respondents respectively disagree or strongly disagree with those statements. The high percentages of responses on the disagree and mostly disagree scales on the reversed items indicates a certain degree of global perspective.

\subsubsection{The Knowledge Scale}

The Knowledge scale is composed of 5 items that measure the "degree of understanding and awareness of various cultures and their impact on our global society and level of proficiency in more than one language" (Braskamp et al., 2013, p. 5). Overall, the participants show an understanding and awareness of cultures and current issues with a mean response score of 2.41 . The three highest items ranked in the scale were: $55 \%$ of the respondents agree with the statement $I$ can discuss cultural differences from an informed perspective, followed by $53 \%$ level of agreement with the statement I know how to analyze the basic characteristics of a culture, and $51 \%$ agreeing with the statement $I$ understand how various cultures of this world interact socially.

\subsubsection{Intrapersonal Dimension Descriptive Statistics}

\subsubsection{Intrapersonal Identity Scale}

The Intrapersonal Identity scale presents an overview of the level of awareness of one's identity in terms of accepting one's own personal ethnicity, racial, and gender components. Overall, this subscale shows that respondents seem to possess a high level of awareness of their identities (Who they are). All 7 items of the scales report highest percentages in the strongly agree and agree levels of the Likert scale. The following items represent the highest percentages on the scale: I have definite goals for my life (78\%); I know who I am as a person (68\%); and I can explain my personal values to people who are different from me (49\%).

\subsubsection{Intrapersonal Affect scale}

This subscale reports the respondents' level of respect and acceptance towards other cultures different than one's own. It also shows the respondents' emotional intelligence (Braskamp et al., 2013: p. 4) when encountering other cultures. Overall, the respondents seem to show a high level of respect towards other cultures. This Intrapersonal Affect is seen in all items of the subscale. The following reversed items displayed high percentages of disagreeing and strongly disagreeing responses: I feel threatened around people from backgrounds very different from my own (69\%); I get offended often by people who do not understand my point-of-view (43\%), and I constantly need affirmative confirmation about myself from others (71\%). It is also interesting to point out that $64 \%$ of the respondents see themselves as global. This supports the results of these reversed-scored items.

\subsubsection{Interpersonal Dimension Descriptive Statistics}

\subsubsection{Interpersonal Social Responsibility subscale}

The interpersonal-social responsibility subscale describes the respondents' "level of interdependencies and social concern for others" (Braskamp et al., 2013). A review of the 5 items in this subscale seems to indicate that 
respondents overall have a high level of social concern for others, an attribute of global citizenship. Some of the statements that support this tendencies are: I think of my life in terms of giving back to society $(87 \%$ agreeing and strongly agreeing with the statement); I consciously behave in terms of making a difference (89\% agreeing and strongly agreeing with the statement); and Volunteering is not an important propriety in my life (79\% disagreeing and strongly disagreeing with the statement). Yet, it is interesting to highlight two statements in particular: I work for the rights of others and I put the needs of others above my own personal wants. Participants did report a majority of responses on the neutral (35\% and 30\% respectively) and agree (42\% and 34\% respectively) Likert-scale section in regards to these statements. This indicates a possible contradiction among the respondents' attitudes towards social responsibility in regards to the rights and needs of others.

\subsubsection{Interpersonal Social Interaction Subscale}

The interpersonal-social interaction scale looks at the level of interaction with cultures different than one's own and the level of cultural sensitivity. Overall, the results illustrate a mix tendency toward interaction with individuals from other cultures. The following statements represent such mix tendencies: Most of my friends are from my own ethnic background (82\% agreeing and strongly agreeing); People from other cultures tell me that I am successful at navigating their cultures (20\% agreeing and $49 \%$ neutral), I am able to take on various roles as appropriate in different cultures and ethnic settings (35\% agreeing and $40 \%$ neutral). On the other hand, the following statements indicate a favorable tendency toward appreciation of other cultures: I enjoy when my friends from other cultures teach me about our cultural differences (45\% agreeing and $24 \%$ neutral), and I am open to people who strive to live lives very different from my own life style ( $46 \%$ agreeing and $26 \%$ neutral).

\subsection{Curriculum Descriptive Statistic}

The curriculum section reports the number of curricular courses taken by the respondents that promote global perspective/global engagement/service learning. Overall, the descriptive analysis indicates that the participants have taken very few courses ( 0 to 1$)$ in areas enhancing a global understanding or views. The following items highlight this analysis: World Geography, 59\% have taken 0 courses while $41 \% 1$ course; World History, $45 \%$ have taken 0 courses while 26\% 1 class; Foreign Language, 44\% have taken 0 courses while $41 \% 1$ course, and Course focused on significant global/international issues and problems, $44 \%$ have taken 0 courses while $41 \% 1$ course. On the other hand, the participants seems to have completed more Multicultural courses addressing issues of race, ethnicity, gender, class, religion, or sexual orientation; $43 \%$ have taken 1 course while $25 \% 2$ courses.

\subsection{Co-Curricular Descriptive Statistics}

The co-curricular items focus on activities that participants have taken part in outside of the classrooms that not only promote global understanding but also a holistic personal development. The co-curricular section has an average mean score of 3.2. This mean score seems to indicate that respondents often participate in activities outside the classroom related to personal and professional development.

Some of the items with the highest scores include: Participated in leadership programs that stress collaboration and team work (36\% reported seldom, $18 \%$ often, and $20 \%$ very often), Discussed current events with students and/or colleagues (23\% reported seldom, 32\% often, and 34\% very often), and Followed an international event/crisis (e.g., through newspaper, social media, or other media source) (36\% reported seldom, $22 \%$ often, and $29 \%$ very often). Yet, three specific items related to developing a global perspective reported scores toward the never, rarely, and sometimes side of the scale. The items were: Attended a lecture/workshop/campus discussion on international/global issues (29\% reported never, $31 \%$ rarely, and $26 \%$ sometimes); Interacted with people from a country different from your own ( $25 \%$ rarely and $38 \%$ sometimes); and Interacted with people from a racelethnic group different than your own (31\% rarely and $42 \%$ sometimes).

\subsection{Community Descriptive Statistics}

The community section reports on the participants' perceptions on the support provided by their communities to their own personal development. Overall, respondents have a positive perception of their communities, and report a strong sense of affiliation to the school they work in ( $83 \%$ level of agreement), and that they have been encouraged to develop their strengths and talents where they work ( $90 \%$ level of agreement). However, such high levels of agreements are not seen in reference to promoting internationalism and diversity in the school community. Only $47 \%$ agree with the statement I feel that my school community honors diversity and internationalism while $28 \%$ felt neutral toward the same statement. These scores seem to be aligned with the lack of co-curricular opportunities promoting the development of a global perspective. 


\subsection{Statistical Analysis of the GPI}

The following section addresses Question 2 of the study, "Is there a statistically significant difference in teachers' global perspectives GPI sub-scales by demographic characteristics and experiences abroad?"

\subsubsection{GPI Sub-scales and Gender}

The overall T-test analysis shows that there is a statistically significant difference between gender and the Cognitive Scale, Knowledge Subscale. In particular, females scored significantly higher than men. No statistically significant difference was reported between gender and the other subscales of the GPI. This indicates that the differences in the GPI subscales are not likely due to gender.

\subsubsection{GPI Sub-scales and Study Abroad}

The overall T-test analysis shows that two subscales - Knowing $(\mathrm{p}=0.003)$ and Interpersonal Social Interaction $(\mathrm{p}=0.014)$ subscales did report a statistically significant difference with regards to study abroad experiences. Those with study abroad experience demonstrated significantly higher cognitive knowing subscales and higher interpersonal social interaction scores. Study abroad experiences tend to expose individuals to diverse perspectives causing them to move outside of their comfort zone.

\subsubsection{GPI Sub-scales and Teachers Preparation}

An ANOVA test was conducted to compare the effect of the level of teacher preparation on teachers' global perspective scales and subscales. The ANOVA results indicate that there is a statistical significance or interaction between the Intrapersonal Identity $[\mathrm{F}(6,142)=1.960, p=0.0375]$ and Intrapersonal Affect $[\mathrm{F}(6,142)=2.068, p=0.045]$ subscales teachers' preparation/educational level.

\section{Discussion of Findings}

Results from items in the Cognitive Dimension Knowing subscale indicate that there is a neutral disposition from respondents. This subscale requires a level of reflectiveness to understand the degree of complexity in one's views in terms of determining what is worth valuing. These results are significant in that it suggests that these respondents may take the role of culture for granted when making decisions or judging what is important to know and value. The respondents, however, indicate a willingness to take into account different perspectives when evaluating global problems and when coming to conclusions about the world (the Knowledge subscale). Participants demonstrated an understanding and awareness of different cultures and current global issues. Overall it seems that the Jamaican teachers in this study had knowledge of other cultures and perspectives but lack an awareness of how their own culture influences their decision about what is important to know and value.

The majority of teachers scored high in Intrapersonal categories related to having personal goals and results indicate individuals have an awareness of who he or she is as a person (the Identity subscale). Overall the respondents seemed to show high level of respect for other cultures, rejecting notions that they feel threatened around people from different backgrounds or that they are offended when people do not understand their point-of-view (the Affect subscale). These perceptions were reinforced by the notion that the majority of the teachers surveyed saw themselves as a global citizen.

Finally, results on the Interpersonal Social Interactions section of this survey offered mix tendencies. Many teachers reported primarily having homogeneous friendship groups and responded that they did not feel they could successfully navigate cross-cultural interactions. Yet scores indicated that more teachers were either supportive or neutral in terms of accepting people that maintain a lifestyle different than her or his own (Social Interactions subscales). In addition teachers did demonstrate some social concern for others. These teachers identified that volunteering was an important part of their lives and felt they could make a difference in society addressing the interdependent aspect of Social Responsibility. It is interesting to highlight that social concern towards others and taking action to improve conditions are important skills for global perspective development. Yet while these teachers value volunteerism they admitted that they do not work for the rights of others or put others' needs above their own. Therefore attempts to become involved with the local community may be geared towards interacting with or giving to others, rather than actions to fight for social justice.

The results on the curriculum, co-curriculum, and community experiences sections identify that experiences related to developing a holistic and global perspective are low. The results, thus, seems to indicate the need for Jamaican institutions to focus on fostering "the relationships and connections between student learning and development and student experiences in the curriculum, co-curriculum, and community" (Braskamp, et al., n.d., p. 2). This reinforces the need for Jamaican educational institutions to promote a curriculum conducive for global perspective development 
and provide co-curricular opportunities to support these goals. These are especially important for post-secondary programs that train teachers. Example of such actions could entail providing cross-cultural seminars and workshops, language training, internationalizing faculty and staff, and utilizing technology to facilitate cross-cultural dialogue.

This research also demonstrated that although the teachers feel that their communities support them, they reported that they were not exposed to cultural diversity within their communities. This finding shed light to the role the community can play in promoting exposure to diverse cultures. Jamaican communities (or parishes) can benefit from enhancing partnerships with the tourism and business sectors. These sectors in particular offer access to diverse cultures and can facilitate in-service teachers' exposure to these resources through community events.

Miller-Perrin and Thompson (2014) state that participating in study abroad experiences not only promotes an "increase in external connections, manifested through an increased ability to converse in another tongue, and an increased understanding, sensitivity, and connection to another culture, but also an internal redirection, resulting in a deepening sense of one's identity and self-awareness" (p. 78). This aligns with the findings that study abroad experiences influence individuals' Cognitive Knowing and higher Interpersonal Social Interaction scores. Unfortunately, only $9 \%$ of the respondents have reported participating in study abroad programs.

Finally, the education level of the teachers seems to enhance awareness of how ethnicity, race, and gender impact one's identity (Intrapersonal Identity) and the level of respect for, or acceptance of, diverse cultural perspectives (Intrapersonal Affect). This knowledge and these dispositions, hence, will facilitate the incorporation of others' view points in the curriculum. This highlights the importance for teachers to engage in life-long learning and professional development process.

Teachers that have developed a global perspective are more likely to incorporate global education into their instruction (Braskamp, Braskamp, \& Engberg, 2013). While we cannot generalize across the population, Jamaica's ministry of education can use these results to design professional growth opportunities that help teachers develop a global perspective. In addition, teacher education seems to have a statistically significant impact on teachers' Intrapersonal Identity and Affect scales, factors contributing to the development of a global perspective. This study highlights recognizable trends in relation to curricula and co-curricular activities. For example respondents had limited exposure to foreign language and world geography courses. Respondents have either never attended or only attended one lecture or workshop discussing international and global issues. Many have rarely interacted with individuals from a different country or interacted with people from a racial/ethnic group different than their own. In order to fulfill the ministry's requirements of globalizing Jamaica, K-16 educational institutions may want to think about incorporating activities that ask students to discuss international issues, schedule more lectures surrounding global topics or offer workshops on intercultural education.

\section{Implications of the Study}

The findings of the study have implications for policy and practice in education. At the policy level, this study provides a baseline for Jamaican teachers' perspectives. As the world is becoming increasingly more connected $21^{\text {st }}$ century learners need to become globally competent. In fact, the Jamaican government recognizes this in many of the reforms found in the Vision 2030 development plan. One crucial component is the development of a global perspective. The purpose of this study was to determine in-service teachers' level of global perspective to gain insight into the potential for Jamaican educational institutions to initiate educational movements towards developing global competence.

This study has pedagogical and research implications for the Jamaica nation, as well as other nations seeking to incorporate global education. Tertiary institutions preparing teachers should benefit from assessing their programs' content knowledge and the field practices provided to in-services teachers that facilitate the development of a global perspective. Reflective questions such as "How do you try to encourage students to reflect on the issue that people from different cultures and countries may think differently about the role of government, religion, family values, schooling, and work and labor requirements?" (Cognitive Domain), "How do you provide opportunities in classes or arrange sessions for students to talk about their own values, sense of self and purpose of life, and relationships with others not like them?" (Intrapersonal Domain), and "How do you assist students to be more comfortable in interactions with other students, staff, faculty, and citizens from different cultural backgrounds, values, and points of view?" (Interpersonal Domains) (Braskamp, et al., 2013, pp.21-22). These questions can serve as a guiding framework when reevaluating the curriculum of teachers programs.

At the practical level, this study indicated that while the Jamaican teachers had knowledge of other cultures and perspectives (the Knowing subscale) they were not very aware on how their own culture influences what they 
determined is important to know and value. While these results cannot be generalized to other people and places, it is important for global educators to recognize how these components, culture and perspectives, are not necessarily mutually inclusive. A curriculum that is geared towards developing a global perspective should incorporate experiences or practices that cause individuals to reflect and become conscious of the taken-for-granted assumptions they make, or values they hold, in an effort to examine how their own culture impacts their decisions.

This research study also indicated that the Jamaican respondents felt close to, and supported by, their community and often felt compelled to participate in volunteer opportunities. However, these teachers also responded that they were not exposed to cultural diversity within this community. These results can have implications for homogenous communities throughout the world. It suggests that simply increasing community involvement does not translate into exposure to diverse cultural ideas and perspectives. Pedagogical attempts to facilitate global perspective development through community engagement must concentrate on providing and facilitating these cross-cultural interactions. While universities may serve as a conduit for these experiences, many institutions of higher learning also have a primarily homogenous population in terms of students' cultural background. Thus cross-cultural interactions may be facilitated through increased access to social networking technologies, e.g. email, skype, Twitter, Facebook, Adobe connect, Whatsapp, Google Chat etc. The responsibility for implementing cross-cultural interactions amongst the community should not rest solely on colleges and universities. Instead businesses, governmental entities, and non-profit organizations should also be brought to the table within developing these pedagogical experiences.

Finally, our study indicated that there was a correlation between the Jamaican teachers' experiences in study abroad programs and higher levels on the Knowing and Interpersonal Social Interaction scales. This supports the goals of many study abroad programs in that participants demonstrated an increased awareness of global issues and cultural perspectives after travelling abroad (Miller-Perrin \& Thompson, 2014). These results also reaffirm research that indicates study abroad experiences offer participants a higher degree of interaction with geographically and culturally diverse others while increasing an individuals' cultural sensitivity (Lewin, 2009; Meyer-Lee \& Evans, 2007). However, there was no correlation between study abroad and levels of social responsibility in this study; suggesting that just because an individual knows and interacts with cultures that differ from their own, they may not feel socially responsible for others around the world. Educational entities at primary, secondary, and postsecondary levels, should all seek to increase the types of study abroad experiences tailored to facilitate cross-cultural interactions that increase participants' social responsibility.

\subsection{Research Implications}

The study was conducted to provide a baseline on Jamaican teachers' global perspectives. This study responded directly to the lack of research addressing this topic. The researchers hope that this study will promote further research on the status of teachers' global perspectives in Jamaica as well as other components of global education. The researchers recommend that additional analysis should include areas outside the Kingston area in Jamaica to allow for generalization. In addition, this study could also be conducted in other Caribbean nations to promote a comparative analysis of in-service teachers' perspectives in the Caribbean.

One of the limitations of the study came from the application of a purposeful sampling. Further research should strive for the application of random sample and an equal balance between males and females respondents. This will allow the researchers to demonstrate if a statistically significant difference between gender and the Cognitive Scale, Knowledge Subscale exits assuming a balanced ratio between males and females respondents. Researchers could also employ qualitative research methodologies to capture more nuanced understandings of Jamaican teachers' global perspectives.

\section{Conclusion}

Teachers that have developed a global perspective are more likely to incorporate global education into their instruction (Braskamp, Braskamp, \& Engberg, 2013; Zhao, 2010; Zong, 2009). While we cannot generalize across the population, Jamaica's Ministry of Education can use these results to promote professional development opportunities that enhance the teachers' global perspectives. In addition, teacher education seems to have a statistically significant impact on teachers' Intrapersonal Identity and Affect scales, significant factors contributing to the development of a global perspective. The study highlights recognizable trends in relation to curricula and co-curricular activities. For example respondents had limited exposure to foreign language and world geography courses. Respondents have either never attended or only attended one lecture or workshop discussing international and global issues. Many have rarely interacted with individuals from a different country or interacted with people from a racial/ethnic group different than their own. In order to fulfill the ministry's requirements of globalizing Jamaica, K-16 educational 
institutions may want to think about incorporating activities that ask students to discuss international issues, schedule more lectures surrounding global topics or offer workshops on intercultural education.

\section{References}

Abdullahi, S. (2010). Rethinking global education in the twenty-first century. In J. Zajda (Ed.), Global pedagogies: Schooling for the future, globalization, comparative education and policy research (pp. 23-34). New York, NY: Springer Dordrecht Heidelberg.

Becker, J. (1979). Schooling for a Global Age. New York: McGraw-Hill.

Boix, Mansilla, \& Jackson, A. (2011). Educating for global competence: Preparing our youth to engage the world. Retrieved from http://asiasociety.org/files/book-globalcompetence.pdf

Braskamp, L., Braskamp, D., \& Engberg, M. (n.d) Global Perspective Inventory (GPI). Retrieved from: https://gpi.central.edu/supportDocs/GPI-Brochure.pdf

Braskamp, L., Braskamp, D., \& Engberg, M. (2013). Global Perspective Inventory (GPI); Its Purpose, Construction, Potential Uses, and Psychometric Characteristics. Retrieve from https://gpi.central.edu/supportDocs/manual.pdf

Braskamp, L., Trautvetter, L., \& Ward, K. (2006). Putting Students First; How Colleges Develop Students Purposefully. Boston: Anker.

Bruce, M., Podemski, R., \& Anderson, C. (1991). Developing a global perspective: Strategies for Teacher Education Programs. Journal of Teacher Education, 42(1), 21-27. http://dx.doi.org/10.1177/002248719104200104

Castle, S. (2007). Migration, citizenship, and education. In J. A. Banks (Ed.), Diversity and citizenship education: Global perspectives (pp. 17-48). San Francisco, CA: John Wiley \& Sons.

Doscher, L., \& Doscher, S. (2013). Global learning for global citizenship. In A. Boni \& M. Walker (Eds.), Human development and capabilities: Re-imagining the university of the twenty-first century (pp. 162-177). New York, NY: Routledge.

Friedman, T. (2012). The Lexus and the olive tree: Understanding globalization. New York, N.Y.: Picador

Gaudelli, W. (2003). World class: Teaching and learning in global times. Mahwah, NJ: Erlbaum Associates.

Ghemawat, P. (2013, September). Why the world isn't flat. Retrieved from http://www.foreignpolicy.com/articles/2007/02/14/why_the_world_isnt_flat

Government of Jamaica. (2012). Vision 2030 Jamaica. Kingston: Planning Institute of Jamaica. Retrieved from http://www.vision2030.gov.jm/

Hanvey, R. (1976). An attainable global perspective. Retrieved from http://www.globaled.org/An_Att_Glob_Persp_04_11_29.pdf

Kegan, R. (1994). In over our heads: The mental demands of modern life. Cambridge, MA: Harvard University Press.

Landorf, H. (2009). Toward a philosophy for global education. In T. Kirkwood-Tucker (Ed.), Visions in global education: The globalization of curriculum and pedagogy in teacher education and schools (pp.47-67). New York, NY: Peter Lang Publishing.

Lewin, R. (2009). Introduction: The quest for global citizenship through study abroad. In R. Lewin (Ed.), The Handbook of Practice and Research in Study Abroad (pp.xiii-xxii). New York, N.Y.: Routledge.

Marber, P. (2013). Globalization and its contents. In R. M. Jackson (Ed.), Global issues 12/13. New York, NY: McGraw-Hill.

Mason, T., \& Serriere, S. (2008). Macedonian and U.S. students in a pre-service teaching cultural exchange: Examining the formation of perspective consciousness. International Journal of Social Education, 23(1), 76-98.

Merryfield, M., \& Subedi, B. (2006). Decolonizing the mind for world-centered global education. In Ross, E.W. (Ed.), The social studies curriculum: Purposes, problems and possibilities (6 $6^{\text {th }}$ ed., pp. 283-296). New York, NY: SUNY.

Merryfield, M., \& Wilson, A. (2005). Social studies and the world: Teaching global perspectives ( ${ }^{\text {st }}$ ed). National Council for the Social Studies, Bulletin 103. Silver Springs, MD: NCSS.

Meyer-Lee, E., \& Evans, J. (2007). Areas of study in outcomes assessment. In M.C. Bolen (Ed.), A Guide to Outcomes Assessment in Education Abroad (pp. 61-70). Carlisle, PA: The Forum on Education Abroad. 
Miller-Perrin, C., \& Thompson, D. (2014). Outcomes of Global Education: External and Internal Change Associated with Study Abroad. New Directions for Student Services, 2014(146), 1-96. http://dx.doi.org/10.1002/ss.20093

Noddings, N. (2005). Educating citizens for global awareness. New York, NY: Teachers College Press.

Palfrey, J., \& Gasser, U. (2008). Born digital: Understanding the first generation of digital natives. New York, N.Y.: Basic Books

Pike, G. (2015). Re-imaging global education in the neoliberal age. In R. Reynolds \& D. Bradbery (Eds.), Contesting and Constructing International Perspectives in Global Education (11-25). The Netherlands: Sense Publishing.

Suarez-Orozco, M. (2004). Globalization: Culture \& education in the new millennium. Los Angeles, CA: University of California.

Wilson, A. H. (1983). A case study of two teachers with cross-cultural experiences. They know more. Educational Research Quarterly, 8(1), 78-85.

Zhao, Y. (2009, September). Needed: Citizens Wanted. Educational Leadership, 67(1), 60-65.

Zhao, Y. (2010). Preparing globally competent teachers: A new imperative for teacher education. Journal of Teacher Education, 61(5), 422-431.

Zong, G. (2009). Global perspectives in teacher education research and practice. In T. Kirkwood-Tucker (Ed.), Visions in global education: The globalization of curriculum and pedagogy in teacher education and schools. (pp.71-89). New York, NY: Peter Lang Publishing.

\section{Appendices}

Knowing scores

\begin{tabular}{|c|c|c|c|c|c|c|c|}
\hline \multirow[t]{2}{*}{ Cognitive -- Knowing } & \multirow[t]{2}{*}{$\mathrm{R}$} & \multicolumn{5}{|c|}{ Percent of Respondents } & \multirow[t]{2}{*}{ Mean } \\
\hline & & $S A(5)$ & $A(4)$ & $N(3)$ & $D(2)$ & $S D(1)$ & \\
\hline $\begin{array}{l}\text { When I notice cultural } \\
\text { differences, my culture tends to } \\
\text { have the better approach. }\end{array}$ & * & $16 \%$ & $36 \%$ & $35 \%$ & $12 \%$ & $2 \%$ & 2.49 \\
\hline $\begin{array}{l}\text { Some people have a culture and } \\
\text { others do not. }\end{array}$ & $*$ & $9 \%$ & $17 \%$ & $12 \%$ & $36 \%$ & $26 \%$ & 3.52 \\
\hline $\begin{array}{l}\text { In different settings what is right } \\
\text { and wrong is simple to } \\
\text { determine. }\end{array}$ & $*$ & $20 \%$ & $39 \%$ & $17 \%$ & $17 \%$ & $7 \%$ & 2.52 \\
\hline $\begin{array}{l}\text { I take into account different } \\
\text { perspectives before drawing } \\
\text { conclusions about the world } \\
\text { around me. }\end{array}$ & & $35 \%$ & $47 \%$ & $12 \%$ & $5 \%$ & $0 \%$ & 1.9 \\
\hline $\begin{array}{l}\text { I consider different cultural } \\
\text { perspectives when evaluating } \\
\text { global problems. }\end{array}$ & & $16 \%$ & $46 \%$ & $27 \%$ & $9 \%$ & $1 \%$ & 2.33 \\
\hline $\begin{array}{l}\text { I rely primarily on authorities to } \\
\text { determine what is true in the } \\
\text { world. }\end{array}$ & $*$ & $4 \%$ & $11 \%$ & $22 \%$ & $40 \%$ & $24 \%$ & 3.68 \\
\hline $\begin{array}{l}\text { I rarely question what I have } \\
\text { been taught about the world } \\
\text { around me. }\end{array}$ & $*$ & $3 \%$ & $20 \%$ & $25 \%$ & $36 \%$ & $15 \%$ & 3.40 \\
\hline $\begin{array}{l}\text { Cultural differences make me } \\
\text { question what is really true. }\end{array}$ & & $16 \%$ & $29 \%$ & $25 \%$ & $26 \%$ & $5 \%$ & 2.75 \\
\hline
\end{tabular}


Knowledge Scores

\begin{tabular}{|c|c|c|c|c|c|c|}
\hline \multirow[t]{2}{*}{ Cognitive -- Knowledge } & \multicolumn{5}{|c|}{ Percent of Respondents } & \multirow[t]{2}{*}{ Mean } \\
\hline & $S A(5)$ & $A(4)$ & $N(3)$ & $D(2)$ & $S D(1)$ & \\
\hline $\begin{array}{l}\text { I am informed of current } \\
\text { issues that impact } \\
\text { international relations. }\end{array}$ & $15 \%$ & $45 \%$ & $32 \%$ & $8 \%$ & $1 \%$ & 2.34 \\
\hline $\begin{array}{l}\text { I understand the reasons and } \\
\text { causes of conflict among } \\
\text { nations of different cultures. }\end{array}$ & $7 \%$ & $47 \%$ & $36 \%$ & $8 \%$ & $2 \%$ & 2.51 \\
\hline $\begin{array}{l}\text { I understand how various } \\
\text { cultures of this world interact } \\
\text { socially. }\end{array}$ & $9 \%$ & $51 \%$ & $34 \%$ & $6 \%$ & $1 \%$ & 2.39 \\
\hline $\begin{array}{l}\text { I know how to analyze the } \\
\text { basic characteristics of a } \\
\text { culture. }\end{array}$ & $7 \%$ & $53 \%$ & $29 \%$ & $9 \%$ & $2 \%$ & 2.45 \\
\hline $\begin{array}{l}\text { I can discuss cultural } \\
\text { differences from an informed } \\
\text { perspective. }\end{array}$ & $9 \%$ & $55 \%$ & $27 \%$ & $8 \%$ & $1 \%$ & 2.36 \\
\hline
\end{tabular}

An "*" means that respondents with a global perspective will disagree with the statement and thus a lower average score indicates a more global perspective.

Intrapersonal Identity Scores

\begin{tabular}{|c|c|c|c|c|c|c|}
\hline \multirow[t]{2}{*}{ Intrapersonal- Identity } & \multicolumn{5}{|c|}{ Percent of Respondents } & \multirow[t]{2}{*}{ Mean } \\
\hline & $S A(5)$ & $A(4)$ & $N(3)$ & $D(2)$ & $S D(1)$ & \\
\hline I have definite goals for my life. & $78 \%$ & $21 \%$ & $1 \%$ & $0 \%$ & $0 \%$ & 1.24 \\
\hline $\begin{array}{l}\text { I can explain my personal values } \\
\text { to people who are different from } \\
\text { me. }\end{array}$ & $49 \%$ & $40 \%$ & $7 \%$ & $3 \%$ & $2 \%$ & 1.69 \\
\hline I know who I am as a person. & $68 \%$ & $24 \%$ & $5 \%$ & $2 \%$ & $1 \%$ & 1.44 \\
\hline $\begin{array}{l}\text { I am confident that I can take } \\
\text { care of myself in a completely } \\
\text { new situation. }\end{array}$ & $35 \%$ & $45 \%$ & $14 \%$ & $6 \%$ & $0 \%$ & 1.74 \\
\hline $\begin{array}{l}\text { I put my beliefs into action by } \\
\text { standing up for my principles. }\end{array}$ & $49 \%$ & $42 \%$ & $6 \%$ & $2 \%$ & $0 \%$ & 1.60 \\
\hline $\begin{array}{l}\text { I am developing a meaningful } \\
\text { philosophy of life }\end{array}$ & $35 \%$ & $51 \%$ & $10 \%$ & $3 \%$ & $1 \%$ & 1.82 \\
\hline $\begin{array}{l}\text { I am willing to defend my own } \\
\text { views when they differ from } \\
\text { others. }\end{array}$ & $45 \%$ & $44 \%$ & $6 \%$ & $5 \%$ & $0 \%$ & 1.71 \\
\hline
\end{tabular}

An "** means that respondents with a global perspective will disagree with the statement and thus a lower average score indicates a more global perspective. 
Intrapersonal Affect Scores

\begin{tabular}{|c|c|c|c|c|c|c|c|}
\hline \multirow[t]{2}{*}{ Intrapersonal- Affect } & \multirow[t]{2}{*}{$\mathrm{R}$} & \multicolumn{5}{|c|}{ Percent of Respondents } & \multirow[t]{2}{*}{ Mean } \\
\hline & & $S A(5)$ & $A(4)$ & $N(3)$ & $D(2)$ & $S D(1)$ & \\
\hline $\begin{array}{l}\text { Ifeel threatened around people from } \\
\text { backgrounds very different from my } \\
\text { own. }\end{array}$ & $*$ & $2 \%$ & $7 \%$ & $22 \%$ & $40 \%$ & $29 \%$ & 3.87 \\
\hline $\begin{array}{l}\text { I often get out of my comfort zone to } \\
\text { better understand myself. }\end{array}$ & & $12 \%$ & $43 \%$ & $20 \%$ & $19 \%$ & $6 \%$ & 2.63 \\
\hline I see myself as a global citizen. & & $20 \%$ & $44 \%$ & $28 \%$ & $8 \%$ & $1 \%$ & 2.27 \\
\hline $\begin{array}{l}\text { I get offended often by people who do } \\
\text { not understand my point-of-view. }\end{array}$ & $*$ & $15 \%$ & $18 \%$ & $25 \%$ & $33 \%$ & $10 \%$ & 3.05 \\
\hline $\begin{array}{l}\text { I am sensitive to those who are } \\
\text { discriminated against. }\end{array}$ & & $38 \%$ & $44 \%$ & $11 \%$ & $5 \%$ & $1 \%$ & 1.87 \\
\hline $\begin{array}{l}\text { I do not feel threatened emotionally } \\
\text { when presented with multiple } \\
\text { perspectives. }\end{array}$ & & $19 \%$ & $46 \%$ & $27 \%$ & $9 \%$ & $0 \%$ & 2.26 \\
\hline $\begin{array}{l}\text { I am accepting of people with different } \\
\text { religious and spiritual traditions. }\end{array}$ & & $28 \%$ & $44 \%$ & $22 \%$ & $4 \%$ & $2 \%$ & 2.07 \\
\hline $\begin{array}{l}\text { I constantly need affirmative } \\
\text { confirmation about myself from others. }\end{array}$ & $*$ & $2 \%$ & $9 \%$ & $18 \%$ & $41 \%$ & $30 \%$ & 3.88 \\
\hline
\end{tabular}

An "*" means that respondents with a global perspective will disagree with the statement and thus a lower average score indicates a more global perspective.

Interpersonal-Social Responsibility scores

\begin{tabular}{|c|c|c|c|c|c|c|c|}
\hline \multirow{2}{*}{$\begin{array}{l}\text { Interpersonal- Social } \\
\text { Responsibility }\end{array}$} & \multirow[t]{2}{*}{$\mathrm{R}$} & \multicolumn{5}{|c|}{ Percent of Respondents } & \multirow[t]{2}{*}{ Mean } \\
\hline & & $S A(5)$ & $A(4)$ & $N(3)$ & $D(2)$ & $S D(1)$ & \\
\hline $\begin{array}{l}\text { I think of my life in terms of } \\
\text { giving back to society. }\end{array}$ & & $35 \%$ & $49 \%$ & $10 \%$ & $5 \%$ & $2 \%$ & 1.89 \\
\hline I work for the rights of others. & & $13 \%$ & $42 \%$ & $35 \%$ & $9 \%$ & $1 \%$ & 2.44 \\
\hline $\begin{array}{l}\text { I put the needs of others above } \\
\text { my own personal wants. }\end{array}$ & & $13 \%$ & $34 \%$ & $30 \%$ & $14 \%$ & $9 \%$ & 2.72 \\
\hline $\begin{array}{l}\text { I consciously behave in terms of } \\
\text { making a difference. }\end{array}$ & & $46 \%$ & $43 \%$ & $9 \%$ & $1 \%$ & $0 \%$ & 1.65 \\
\hline $\begin{array}{l}\text { Volunteering is not an } \\
\text { important priority in my life. }\end{array}$ & $*$ & $1 \%$ & $7 \%$ & $12 \%$ & $38 \%$ & $41 \%$ & 4.10 \\
\hline
\end{tabular}

An $" * *$ means that respondents with a global perspective will disagree with the statement and thus a lower average score indicates a more global perspective. 
Interpersonal-Social Interaction scores

\begin{tabular}{|c|c|c|c|c|c|c|c|}
\hline \multirow[t]{2}{*}{ Interpersonal- Social Interaction } & \multirow[t]{2}{*}{$\mathrm{R}$} & \multicolumn{5}{|c|}{ Percent of Respondents } & \multirow[t]{2}{*}{ Mean } \\
\hline & & $S A(5)$ & $A(4)$ & $N(3)$ & $D(2)$ & $S D(1)$ & \\
\hline $\begin{array}{l}\text { Most of my friends are from my } \\
\text { own ethnic background. }\end{array}$ & $*$ & $46 \%$ & $36 \%$ & $8 \%$ & $9 \%$ & $1 \%$ & 1.83 \\
\hline $\begin{array}{l}\text { People from other cultures tell me } \\
\text { that I am successful at navigating } \\
\text { their cultures. }\end{array}$ & & $4 \%$ & $20 \%$ & $49 \%$ & $20 \%$ & $7 \%$ & 3.08 \\
\hline $\begin{array}{l}\text { I am able to take on various roles as } \\
\text { appropriate in different cultures and } \\
\text { ethnic settings. }\end{array}$ & & $13 \%$ & $35 \%$ & $40 \%$ & $13 \%$ & $0 \%$ & 2.53 \\
\hline $\begin{array}{l}\text { I prefer to work with people who } \\
\text { have different cultural values from } \\
\text { me. }\end{array}$ & & $5 \%$ & $18 \%$ & $45 \%$ & $26 \%$ & $6 \%$ & 3.12 \\
\hline $\begin{array}{l}\text { I intentionally involve people from } \\
\text { many cultural backgrounds in my } \\
\text { life. }\end{array}$ & & $14 \%$ & $24 \%$ & $31 \%$ & $29 \%$ & $2 \%$ & 2.82 \\
\hline $\begin{array}{l}\text { I enjoy when my friends from other } \\
\text { cultures teach me about our cultural } \\
\text { differences. }\end{array}$ & & $23 \%$ & $45 \%$ & $24 \%$ & $4 \%$ & $5 \%$ & 2.22 \\
\hline $\begin{array}{l}\text { I am open to people who strive to } \\
\text { live lives very different from my } \\
\text { own life style. }\end{array}$ & & $15 \%$ & $46 \%$ & $26 \%$ & $11 \%$ & $2 \%$ & 2.39 \\
\hline
\end{tabular}

An "*" means that respondents with a global perspective will disagree with the statement and thus a lower average score indicates a more global perspective.

Curriculum Scores

\begin{tabular}{lllllll}
\hline Curricular Items & \multicolumn{7}{c}{ Percent Numbers of Courses } & Mean \\
& 0 & 1 & 2 & 3 & 4 & $5+$ \\
& & & & & \\
\hline
\end{tabular}


Co-Curricular Scores

\begin{tabular}{|c|c|c|c|c|c|c|}
\hline \multirow[t]{2}{*}{ Co- Curricular Items } & \multicolumn{5}{|c|}{ Percent of Respondents } & \multirow[t]{2}{*}{ Mean } \\
\hline & $N(0)$ & $R(1)$ & $S(2)$ & $O(3) \quad V($ & (4) & \\
\hline $\begin{array}{l}\text { Participated in events or activities sponsored by } \\
\text { groups reflecting your own cultural heritage }\end{array}$ & $15 \%$ & $23 \%$ & $46 \%$ & $11 \%$ & $5 \%$ & 2.68 \\
\hline $\begin{array}{l}\text { Participated in events or activities sponsored by } \\
\text { groups reflecting a cultural heritage different from } \\
\text { your own }\end{array}$ & $41 \%$ & $28 \%$ & $24 \%$ & $7 \%$ & $0 \%$ & 1.97 \\
\hline Participated in religious or spiritual activities & $3 \%$ & $11 \%$ & $28 \%$ & $23 \%$ & $34 \%$ & 3.73 \\
\hline $\begin{array}{l}\text { Participated in leadership programs that stress } \\
\text { collaboration and team work }\end{array}$ & $3 \%$ & $13 \%$ & $36 \%$ & $30 \%$ & $18 \%$ & 3.47 \\
\hline Participated in community service activities & $8 \%$ & $18 \%$ & $36 \%$ & $18 \%$ & $20 \%$ & 3.24 \\
\hline $\begin{array}{l}\text { Attended a lecture/workshop/campus discussion on } \\
\text { international/global issues }\end{array}$ & $29 \%$ & $31 \%$ & $26 \%$ & $11 \%$ & $2 \%$ & 2.28 \\
\hline $\begin{array}{l}\text { Read a newspaper or news magazine (online or in } \\
\text { print) }\end{array}$ & $3 \%$ & $8 \%$ & $23 \%$ & $32 \%$ & $34 \%$ & 3.86 \\
\hline Watched news programs on television & $1 \%$ & $5 \%$ & $22 \%$ & $22 \%$ & $51 \%$ & 4.17 \\
\hline $\begin{array}{l}\text { Followed an international event/crisis (e.g., through } \\
\text { newspaper, social media, or other media source) }\end{array}$ & $2 \%$ & $10 \%$ & $37 \%$ & $22 \%$ & $29 \%$ & 3.65 \\
\hline $\begin{array}{l}\text { Discussed current events with students and/or } \\
\text { colleagues }\end{array}$ & $1 \%$ & $4 \%$ & $36 \%$ & $33 \%$ & $26 \%$ & 3.78 \\
\hline $\begin{array}{l}\text { Interacted with people from a country different } \\
\text { from your own. }\end{array}$ & $4 \%$ & $25 \%$ & $38 \%$ & $22 \%$ & $10 \%$ & 3.09 \\
\hline $\begin{array}{l}\text { Interacted with people from a race/ethnic group } \\
\text { different than your own }\end{array}$ & $2 \%$ & $31 \%$ & $42 \%$ & $20 \%$ & $4 \%$ & 2.93 \\
\hline
\end{tabular}

Scale: $\mathrm{N}=$ never, $\mathrm{R}=$ rarely; $\mathrm{S}=$ sometimes, $\mathrm{O}=$ often; $\mathrm{VO}=$ very often.

Community Scores

\begin{tabular}{|c|c|c|c|c|c|c|}
\hline \multirow[t]{2}{*}{ Community Items } & \multicolumn{5}{|c|}{ Percent of Respondents } & \multirow[t]{2}{*}{ Mean } \\
\hline & $S A(5)$ & $A(4)$ & $N(3)$ & $D(2)$ & $S D(1)$ & \\
\hline $\begin{array}{l}\text { I have a strong sense of } \\
\text { affiliation with the school I } \\
\text { work in. }\end{array}$ & $43 \%$ & $40 \%$ & $11 \%$ & $4 \%$ & $2 \%$ & 1.83 \\
\hline $\begin{array}{l}\text { I feel that my school } \\
\text { community honors diversity } \\
\text { and internationalism. }\end{array}$ & $17 \%$ & $47 \%$ & $28 \%$ & $6 \%$ & $2 \%$ & 2.28 \\
\hline $\begin{array}{l}\text { I have been encouraged to } \\
\text { develop my strengths and } \\
\text { talents at the school I work in. }\end{array}$ & $38 \%$ & $52 \%$ & $5 \%$ & $1 \%$ & $4 \%$ & 1.82 \\
\hline $\begin{array}{l}\text { I feel I am a part of a close and } \\
\text { supportive community of } \\
\text { colleagues and friends. }\end{array}$ & $26 \%$ & $46 \%$ & $21 \%$ & $5 \%$ & $2 \%$ & 2.10 \\
\hline
\end{tabular}


Study Abroad T-test results

\begin{tabular}{|c|c|c|c|c|c|c|}
\hline \multirow{2}{*}{$\begin{array}{l}\text { Scale Dimensions and } \\
\text { Subscales }\end{array}$} & \multicolumn{2}{|c|}{ Study Abroad } & \multicolumn{2}{|c|}{ SD } & \multirow[t]{2}{*}{ t-Value } & \multirow[t]{2}{*}{$\mathrm{p}$ value } \\
\hline & $\begin{array}{l}\text { Experience } \\
\text { Abroad }\end{array}$ & $\begin{array}{c}\text { No } \\
\text { Experience } \\
\text { Abroad }\end{array}$ & $\begin{array}{l}\text { Experience } \\
\text { Abroad }\end{array}$ & $\begin{array}{l}\text { No } \\
\text { Experience } \\
\text { Abroad }\end{array}$ & & \\
\hline \multicolumn{7}{|l|}{ Cognitive Dimension } \\
\hline Knowledge & 10.63 & 11.85 & 3.03 & 2.82 & -1.651 & 1.01 \\
\hline Knowing & 25.13 & 21.55 & 3.46 & 4.54 & 2.97 & $0.003 *$ \\
\hline \multicolumn{7}{|l|}{ Intrapersonal Dimension } \\
\hline Intrapersonal Identity & 11.55 & 11.77 & 3.22 & 3.28 & -3.024 & 0.746 \\
\hline Intrapersonal Affect & 20.81 & 21.37 & 5.00 & 3.85 & -0.534 & 0.594 \\
\hline \multicolumn{7}{|l|}{ Interpersonal Dimension } \\
\hline $\begin{array}{l}\text { Interpersonal Social } \\
\text { Responsibility }\end{array}$ & 11.06 & 13.34 & 2.29 & 2.75 & -1.792 & 0.074 \\
\hline $\begin{array}{l}\text { Interpersonal Social } \\
\text { Interaction }\end{array}$ & 14.50 & 17.66 & 21.63 & 3.68 & 2.75 & $0.014^{*}$ \\
\hline Total GPI Scale & 92.06 & 96.55 & 4.44 & 13.57 & -1.184 & 0.238 \\
\hline
\end{tabular}

Note: ${ }^{*} \mathrm{p}=<0.05$

Teachers Preparation Anova Results

\begin{tabular}{lcc}
\hline $\begin{array}{c}\text { Scale Dimensions and } \\
\text { Subscales }\end{array}$ & f value & p value \\
\hline Cognitive Dimension & $\mathrm{F}(6,142)=1.630$ & \\
$\quad$ Knowledge & $\mathrm{F}(6,141)=0.828$ & 0.143 \\
$\quad$ Knowing & & 0.050 \\
Intrapersonal & $\mathrm{F}(6,142)=1.960$ & \\
Dimension & $\mathrm{F}(6,142)=2.068$ & $0.0375^{*}$ \\
$\quad$ Intrapersonal Identity & $0.045^{*}$ \\
$\quad$ Intrapersonal Affect & & \\
& & \\
Interpersonal & & 0.145 \\
Dimension & $\mathrm{F}(6,142)=1.662$ & 0.575 \\
$\quad$ Interpersonal Social & $\mathrm{F}(6,142)=0.795$ & \\
$\quad$ Interpersonal Social & & 0.311 \\
Interaction & $\mathrm{F}(6,142)=1.198$ & \\
Total GPI &
\end{tabular}

Note: ${ }^{*} \mathrm{p}=0.05$ 